\title{
Exploring New Avenues for Knowledge Production in Migration Research: A Debate Between Bridget Anderson and Janine Dahinden Pre and After the Burst of the Pandemic
}

\author{
Janine Dahinden* and Bridget Anderson* *
}

Abstract: Janine Dahinden and Bridget Anderson discuss each other's responses to the challenges of knowledge production in migration studies. Dahinden introduces the concept of the "migrant-citizen nexus" and Anderson argues for more attention to be paid to the racialisation of "the migrant" through the ways that nationality elides race and discuss the nationalistic policies adopted in reaction to the pandemic.

Keywords: De-nationalisation, de-migranticisation, migrant-citizen-nexus, racialisation

\section{Nouvelles pistes de production des savoirs dans la recherche sur les migrations: débat entre Bridget Anderson et Janine Dahinden avant et après le déclenchement de la pandémie}

Dans cette contribution, Janine Dahinden et Bridget Anderson discutent leurs réponses respectives aux défis de la production des savoirs dans la recherche sur les migrations. Dahinden introduit le concept de "migrant-citizen nexus" et Anderson estime qu'il est nécessaire de porter une plus grande attention aux processus de racialisation des "migrant.e.s" et à la manière dont la nationalité co-produit simultanément la race et la citoyenneté. Toutes deux discutent des politiques nationalistes adoptées en réaction à la pandémie.

Mots-clés: Dé-nationalisation, dé-migrantisation, migrant-citizen-nexus, racialisation

\section{Neue Wege der Wissensproduktion in der Migrationsforschung: Eine Debatte zwischen Bridget Anderson und Janine Dahinden vor und nach Ausbruch der Pandemie}

Janine Dahinden und Bridget Anderson diskutieren in diesem Beitrag ihre jeweiligen Antworten auf die Herausforderungen, vor denen die Migrationsforschung bezüglich ihrer Wissensproduktion steht. Dahinden führt des Weiteren das Konzept des "migrant-citizen nexus" ein. Anderson argumentiert, dass eine vermehrte Aufmerksamkeit auf Prozesse von "Racialisation" von "Migrant*innen» notwendig ist, da Nationalität gleichzeitig über Staatsbürgerschaft und "race" hergestellt wird. Beide diskutieren die nationalistischen Antworten mit denen die Politik auf die Pandemie antwortete.

Schlüsselwörter: De-Nationalisierung, De-Migrantisierung, Migrant-citizen-nexus, Racialisation

\footnotetext{
* University of Neuchâtel, Laboratory for the Study of Social Processes and nccr - on the move, CH-2000 Neuchâtel, janine.dahinden@unine.ch

** Director Migration Mobilities Bristol, University of Bristol, UK. Bridget.anderson@bristol.ac.uk
} 


\section{Janine Dahinden, University of Neuchâtel, Laboratory for the Study of Social Processes and nccr - on the move, Switzerland}

\section{Introduction}

Bridget Anderson (2019) and I (Dahinden 2016a) have both recently articulated fundamental concerns regarding particular ethical, epistemological and political problems in migration research, and we have both created new concepts to address them. While I have pled for researchers to "de-migranticise" migration and integration research, Anderson has argued for "methodological de-nationalism" by "migrantising citizens". What do our proposals have in common, and how do they speak to each other? Do they represent two sides of the same coin, or do they deal with different issues? The editors of the Swiss Journal of Sociology have asked us to engage in a debate on these questions. It is with enormous pleasure that I have accepted this (in my eyes) challenge.

I will first briefly explain how I understand Anderson's suggestion to migrantise citizens and move towards methodological de-nationalism in migration research. I will then reflect upon possible ways to link Anderson's approach and mine and argue that her suggestions can be considered a particular form of de-migranticisation while also raising new, original issues. I will introduce the concept of the "migrantcitizen nexus" as a way to develop these theoretical considerations further. Finally, I will turn to a more general issue: I will ask what our approaches stand for, on a more theoretical level, regarding the way knowledge is produced within migration studies.

\section{Epistemological and Political Challenges of Migration Research}

Anderson grounds her argument in two significant observations, namely that in political debates, a "migrant" is generally perceived as a person whose movements or presence are problematic, and that the study of migration continues to run the risk of reinforcing the deeply entrenched belief that there are such things as stable national communities whose existence is threatened by migrants (2019, 2). Put differently, Anderson asserts that migration scholars often fail to propose alternative narratives regarding migration and have had little effect in countering the commonly told story of migration as a threat to sovereignty, security, national identity and national culture $(2019,2)$. Accordingly, Anderson reflects on how to do migration research without reinforcing the view of the migrant as a problematic 
subject, hence her proposal to methodologically de-nationalise migration research. She defines "methodological de-nationalism" as

an approach that [...] recognises that borders and citizenship are politically constituted and historically and economically embedded. [...] It makes visible and investigates the workings of state-imposed categories of migrant and citizen in all their differentiations, their impacts on the experiences of individuals and groups, and the management, governance and accountability of national(ised) territories and international/global relations more generally. It recognises the continuing power of the state and the national order of things, how they work together to inform our understanding of 'society', political power and accountability [...]. (2019, 5-6)

A key element of her proposal is to migrantise the citizen: As she argues, the distinction between "migrant" and "citizen" is crucial to the creation and governance of nation-states and their territorial borders. Immigration controls are framed as necessary for the protection of citizens, and "they mark states' claims to prioritise their citizens' needs over those of foreign residents" $(2019,2)$. To migrantise the citizen is to explore the many "connections between the formal exclusion of noncitizenship and the multiple, and sometimes informal exclusions within citizenship" and thus challenge the simplistic opposition between "migrant" and "citizen" (2019, 2). At the core of the investigation, methodological de-nationalism thus places the relationships between immigration, race, nationality, gender and class; the ways they reinforce and are entangled with each other; how they are contested; and how, in practice, all of this complicates the migrant/citizen binary (2019, 10). Anderson offers an insightful and original way to de-centre migration research in order to go beyond its nationalist lens and the normative connotation of migration as a problem.

Similarly to Anderson, 1 have been looking for ways to overcome the nationstate- and ethnicity-centred epistemologies that continue to inform much of migration research. This is important in order to overcome the risk of reproducing through our research particular hegemonic power relations and concomitant forms of social and political exclusion. We are both striving to come to terms with such serious ethical, epistemological and political challenges involved in doing migration research, but without abandoning migration studies altogether.

\section{Towards the Theorisation of a Migrant-Citizen Nexus?}

I have been wondering whether Anderson's attempt to migrantise citizens could be considered a particular, innovative form of de-migranticising research. I proposed a three-fold strategy to de-migranticise research (2016a, 2213-8): I argued that it might be possible to disembed this field of research from the logic of the nation- 
state and normalised discourses of migration-related difference by distinguishing between common-sense and analytical categories, by connecting migration theory more closely with other social-science theories (e.g. using social science concepts from other fields than migration studies like boundary work, gender theories, mobility studies, etc.) and by re-orienting the focus of investigation away from "migrant populations" and towards the "overall population" (e.g. by choosing as units of research neighbourhoods, cities, school classes, etc.). As I understand Anderson's argument, her attempt to migrantise citizens is clearly connected to my plea to change the unit of analysis from migrants to the overall population in order to investigate empirically when and how the category of "migrant" becomes significant - empirically, theoretically and politically. Put differently, Anderson's proposal speaks to my call for de-migranticisation because she expands the focus beyond the object of the "migrant" in two ways. The first involves her inclusion of the non-migrant population in her analysis. On the one hand, she includes the non-migrant population in her analysis in order to explore the ways in which migrancy and citizenry are entangled rather than binary. Anderson demonstrates the many ways in which citizens can be affected by immigration laws. For instance, the recent tendency to criminalise citizens who are engaged in migration politics - by assisting people who cross borders and providing migrants with shelter or food, for example - demonstrates one way in which the migrant/citizen binary becomes entangled. On the other hand, she goes beyond the issue of immigration control $(2019,9)$, which can also be considered a way of de-migranticising research. Anderson argues that immigration controls are mostly attempts to control the mobility of the poor and suggests investigating them as part of a more encompassing governance of the mobility of the poor, whatever their citizenship. She offers as an example attempts to regulate the homeless and panhandlers, who are sometimes deprived of the right to be in particular public spaces, despite their being citizens $(2019,10)$.

Second, Anderson raises an issue that clearly extends beyond my three-fold strategy: She proposes conceiving of "migrantised" people as created by racialised (and classed) processes connected to particular locations within (local and transnational) societies. Her insistence on the "migrant" as a racialised category is both timely and significant and could be considered a fourth strategy of de-migranticisation that I neglected in my proposal. This difference is probably a result of our respective research foci and mirrors the different theoretical anchors of our respective pleas. Strictly speaking, Anderson brings together critical race theories and theories of migration in order to understand the processes at stake, something that, as she rightly argues, migration scholars have been reluctant to do. She argues that once migration is no longer at the border, it becomes "race", and that ethnic-minority citizens are often migrantised $(2019,8)$.

Applying her argument to the case of Switzerland is an interesting endeavour: Switzerland has no knowledge of the post-colonial concept of "ethnic- or racial- 
minority citizens". There are Swiss national minorities, defined on the basis of national language groups, on the one hand, and migrants, or people with a "migration background", on the other. Policies target these two groups very differently (Dahinden 2016b). Of course, racism and processes of racialisation are nevertheless present in Switzerland, but they are entangled with culturalisation processes based on ethnicity (Ossipow et al. 2019). Switzerland has recently been referred to as a "colonialism without colonies" (Purtschert and Fischer-Tiné 2015). Given the Swiss elite's strongly entangled history with colonial powers, but also their role in perpetuating dominant racist representations, ideas and practices - including in colonial scientific networks - processes of racialisation and coloniality are significant in Switzerland as well, although somewhat differently than in "classical" colonial countries. Put differently, racialisation exists in Switzerland, but it is detached from concepts like "ethnic- or racial-minority citizens", and scholars thus face the challenge of theorising and translating ideas based on post-colonial approaches developed in Anglo-Saxon countries with their distinct histories in the context of a "colonialism without colonies".

Swiss scholars have started to work with post-colonial approaches in order to better understand contemporary migration in Switzerland: They have analysed, for example, political propaganda whose "raceless racism" betrays its colonial influences (Michel 2015), shown the influence of colonial discourses in contemporary rightwing discourses about the sexuality of migrants (Fischer and Dahinden 2017) and demonstrated the orientalising nature of discourses arguing that migrant women need to be saved from culturally Other (Muslim) oppressors and assume the supremacy of gender equality among (white) Swiss citizens (Dahinden et al. 2018; Khazai 2019). This research demonstrates the strength of Anderson's argument. I would claim that the ways in which citizens are migrantised can only be properly understood by, on the one hand, recognising the historical colonial embeddedness of systems of dominance and concomitant representations of the "Other" and, on the other hand, by exploring the power of the nation-state logic: Hence, issues of racialisation as much as of culturalisation, ethnicisation, class and gender work intersectionally and need to be investigated carefully.

Finally, I would like to suggest expanding Anderson's approach. There is a flipside to exploring the ways in which citizens are migrantised, one that remains, it seems to me, implicit in Anderson's article and which might be worthwhile making explicit. Therefore, I would like to introduce the concept of a "migrantcitizen nexus". Carling (2017) has recently criticised the "nexification" tendency in migration research, but I think the "migrant-citizen nexus" concept - according to which not only are citizens migrantised, but migrants are also "citizenised" (with my apologies for introducing yet another inelegant term to these debates) - makes it possible to perceive interconnections that otherwise remain invisible. Anderson briefly alludes to this possibility in discussing Isin and Nielson's (2008) concept of 
"acts of citizenship" in terms of politics outside of citizenship (Anderson 2019, 4), but she does not elaborate on it further.

In the case of Switzerland, citizens are migrantised in several ways. For example, descendants of migrants, even when they are citizens, are referred to as "secondgeneration migrants" or "people with a migration background". These terms suggest non-belonging, and that only multigenerational sedentariness in a specific national territory turns a person into a "true" citizen. Also, "migration background" is a highly contested category, mainly used in German-speaking countries, that became transformed from a statistical into a social category, mirroring a shift from class-centred problematisations in statistics to individualising and culturalising ones (Horvath 2019). Both categories indicate that formal citizenship does not coincide perfectly with symbolic membership in the citizenry (Bonjour and Block 2016). Another example of the migrantisation of citizens is the following: Until 1952 Swiss women who married foreigners were deprived of their citizenship. They became foreigners, and in the event of illness or dependency on the welfare state they could be deported. Between 1952 and 1992, women were able to retain their Swiss citizenship by filing a declaration stating their desire to do so upon marriage with a foreigner, but they continued not to have the right to transmit their nationality to foreigners or their children (Studer 2001; Kristol and Dahinden 2019).

At the same time, Switzerland also offers several examples of ways in which migrants become citizenised. For example, many French-speaking cantons grant foreigners voting rights in cantonal and municipal elections and sometimes also the right to hold public office on the cantonal and municipal levels. The history of voting rights in the Canton of Neuchâtel is revealing with respect to the gendered aspects of citizenship. Male foreigners first gained the right to vote at the municipal level in 1849. This right was revoked shortly thereafter and reinstated in 1875 . Swiss women only obtained the right to vote in this canton in 1959 - which was comparatively early, given that women did not have the right to vote in federal elections until 1971. These are all instances of citizenising migrants (while migrantising Swiss female citizens). Migrants are also citizenised by having their human rights recognised by legal instruments such as the Universal Declaration of Human Rights, the European Convention of Human Rights and Title 2 of the Swiss Federal Constitution, which can have clear consequences. For instance, undocumented migrants in Switzerland have the right to basic healthcare. This right is based on the Swiss Federal Constitution and regulated by the Public Health Insurance Law. They also have the right and obligation to possess basic health insurance. But persons without health insurance - including most undocumented migrants - are also entitled to basic medical assistance when in need ${ }^{1}$.

1 https://www.bag.admin.ch/bag/en/home/strategie-und-politik/nationale-gesundheitsstrategien/ gesundheitliche-chancengleichheit/chancengleichheit-in-der-gesundheitsversorgung/gesundheitsversorgung-der-sans-papiers.html (20.6.2020). 
These reflections only hint at the gendered, classed, racialised and ethnicised processes that could be investigated through the theoretical framework of the migrant-citizen nexus. A fuller articulation of this nexus is beyond the scope of this brief commentary,

\section{$4 \quad$ Knowledge Production in Migration Research}

I would like to add a final comment about knowledge production in migration studies more generally. The suggestions to migrantise citizens and de-migranticise migration research are not alone in their attempts to find new avenues for research that avoid reproducing nationally coloured epistemologies. On the contrary, they are deeply anchored in a debate that began 30 years ago. In 1990 Liisa Malkki (1992, 25-6) emphasised that the "national order of things" is not only built into everyday language, but often also implicit into scholarly work. Moreover, it has been 20 years since Andreas Wimmer and Nina Glick Schiller (2002) published their seminal article on methodological nationalism. Anderson mentions a wide body of scholarly work as well - transnational studies, border and mobility studies, post-colonial approaches - which address these challenges and introduce new concepts to avoid reproducing the logic of the nation-state and views of the "migrant other" (2019, 3-5). Likewise, attempts to critically scrutinise categories - as we both undertake to do in our work (e. g. Dahinden et al. 2020) - is far from new in migration research, and there has been a proliferation of such endeavours in recent years. Many scholars have investigated the "work" (nation-)state-based categories do, with what effects and for whom. They have, for instance, scrutinised the political consequences of the label "refugee" (Zetter 1991; Scalettaris 2007; Crawley and Skleparis 2017), the hegemonic connotations and production of gendered and racialised (national) non-belonging through the category of "integration" (Korteweg 2017; Schinkel 2018) and the way migration maps are anchored in and reproduce a national logic (van Houtum and Bueno Lacy 2019), and they have also offered alternatives, for instance by proposing to "de-naturalize the national" in migration research (Amelina and Faist 2012). How can this proliferation be understood, and why is it that scholars have continued to struggle with these challenges for almost 30 years? As I understand it, what is common to this body of work is the attempt to find (ethical and scientifically sound) ways to avoid reproducing hegemonic, racialised and nationalised forms of exclusion in migration research. There is a paradox here, however. Despite this long-lasting debate and the proliferation of such critical or reflexive work, critical or reflexive migration scholars have not succeeded, it seems to me, in anchoring their alternative concepts in academia more broadly. First, mainstream migration research has not yet integrated these ideas, as Adrian Favell (2016) has convincingly argued, and second, many other fields in the social 
sciences have also been quite detached from this wide body of reflexive or critical work, and research often continues to treat the nation-state as, in Anderson's words, "the repository of cultures of nationhood" $(2019,4)$. It seems that we as migration scholars have been caught in a self-referencing circle - detached from other socialscience disciplines and mainstream research - as I tried to explain in my article (Dahinden 2016a). Additionally, we might self-critically ask how we could better introduce these alternative approaches outside academia, in politics for instance, given the toxic climate regarding migration in Europe. Which would be interesting avenues to de-migranticise migration policy, state-funded programmes and NGO projects that exclusively targeting "migrants"? Finally, if we as scholars are not more successful in bringing up other narratives of migration than problem-related ones, we might ask ourselves how migrantised citizens and citizenised migrants contest forms of exclusion, and what alternative narratives they create. Put differently, perhaps we could more rigorously include the situated knowledge of those considered migrantised citizens or citizenised migrants in our knowledge production and give their voices more space in our work. I propose to engage in a debate about these issues, because they seem to me crucial to issues of knowledge production, legitimacy, representation and power relations in migration studies.

\section{Bridget Anderson, Director Migration Mobilities Bristol, University of Bristol, UK}

\section{Introduction}

Janine Dahinden and I both are responding to a challenge that migration scholars have, as she points out, been struggling with for over thirty years: How do we move on from methodological nationalism? How can researchers avoid reproducing states' efforts to fix mobilities' role in social relations in ways that make "the migrant" a racialised and problematic figure? We both seek to move beyond critique to propose ways forward, contributing to the "proliferation" of attempts to think beyond or outside hegemonic nation state-based constructions of "migration".

Those who might self-describe as "critical migration scholars" are in general agreement that "the migrant" is a social construction and that "the migrant" as an identity is relatively recent. This is not because moving about the world is a new phenomenon. What is new, however, is the state and social categorisation of certain people as "migrants". But this leaves open the question concerning the kind of social construction is the migrant is, and relatedly: So what if the "migrant" is socially constructed? It is not social constructs which are drowning in the Mediterranean. 
How does such an analysis help engage with the kinds of injustices that characterise the treatment of migrants?

In her seminal piece in Ethnic and Racial Studies Dahinden (2016a) analyses the problem - the uncritical use of nation-state developed categories that naturalize migration-related difference - and proposes three "ways out": simple acceptance; strategic positive essentialism; and reflexive working to de-naturalise and de-ethnicise the studies of migration and integration. Focusing on the last of these, she puts forward three strategies for pursuing reflexivity: Distinguishing between analytical and common-sense categories, integrating migration research into social theory, and changing the object of study from the migrant population through, for example taking place-based approaches or focusing on bordering practices. In what follows I will respond to that piece with some thoughts of my own, and then consider what that means for the proposal of the analytical lens of the migrant/citizen nexus.

\section{Making Up People in Migration Research}

From the 1970s onwards social theory and the social sciences have debated the challenge methodological nationalism poses to social scientific thinking. Methodological nationalism equates "society" with the modern nation state, naturalising the nation state as a container of social processes. It thereby pre-determines and defines certain objects of sociological enquiry and overlooks others, most crucially the nation state form itself (Wimmer and Glick-Schiller 2002). As social scientific interest in migration and human mobility has grown, so this problem has loomed larger. Scholars of migration continue to find methodological nationalism a particularly vexing epistemological, empirical and ethical challenge, as it normalises controls over cross border mobility and positions the international migrant as transgressing naturalised territorial boundaries and disrupting the "national order of things" (Malkki 1995). Scholars concerned about the uncritical embracing of the nation/state/society as a natural social and political form have become increasingly vocal about the risks of intellectual "co-optation" and the ways that migration/integration scholars can find themselves implicated in nation state making processes (Favell 2015; De Genova 2017; Schinkel 2018; Sharma 2020).

Importantly, this concern about co-optation is not confined to migration studies. Ian Hacking has theorised how human sciences "make up people", and under the rubric of human sciences he includes "many social sciences, psychology, psychiatry and, speaking loosely, a good deal of clinical medicine ... specific sciences should never be defined except for administrative and educational purposes. Living sciences are always crossing borders and borrowing from each other" (Hacking 2006, 23). His work on "dynamic nominalism" builds on and critiques the philosophical nominalist tradition that holds, crudely, that taxonomies are created by human beings. When it 
comes to the classification of people, he argues, names interact with the named, and human action is tightly linked to human description. It is not that bureaucrats and social and human scientists recognise an already existing kind of person, but rather that a kind of person can emerge at the same time as the kind is being invented: The generation of the category generates new possibilities for (or delimitations of) action. In Hacking's analysis, experts and scientists play an important role in what he calls the "looping effect". Experts are important in the initial identification of a potential form of grouping and later in the generation of expert knowledge on the grouping which is both legitimised and disseminated via institutions. One of the examples Hacking gives is of the female refugee in Canada (Hacking 2000, 11), and perhaps a particularly notable contemporary category of relevance to migration researchers is the Victim of Trafficking (VoT). Like other recently identified socialforensic categories, from autism to trans-identity, once identified as a phenomenon, numbers rocket, and the identification changes how people feel about themselves and their experiences, and shapes the possibilities for action. It also becomes an area of expertise and intervention, and we have seen with trafficking a huge increase in the numbers of state functionaries, businesses, NGOs and international organisations generating knowledge and policies about trafficking and, more recently, "modern slavery".

The epistemological and ethical issues of scientific expert knowledge are not confined to migration studies, and neither is the challenge of methodological nationalism, which runs across the social sciences. However, the category of the migrant/ non-citizen, is exceptional because it is integral to the logic of contemporary state making. As John Torpey, following Weber, has argued in his history of the passport, modern states' monopoly over the legitimate means of movement is an essential element of the "state-ness of states" (2000). The state and governance are critical to much social categorisation and population making but what types of populations are made are largely contingent. So for example contemporary European states have made populations using the label "autistic" but they have not made a population of "prophets", though perhaps they will in the future, while COVID-19 means that having a population labelled "COVID-19 immune" makes sense today in ways that would have been inconceivable when Dahinden and I wrote our respective pieces. However, the form of the nation state is such that the labelling of some people as "nationals" and others as "non-nationals" or "migrants" is not contingent but necessary. Nation states can make many different and varied kinds of populations. They may or may not make an autistic population, but they must make "migrants" if they are to be a nation state (Sharma 2020). Importantly the migrant is not the only group that is foundational to contemporary nation state making. Others might include the criminal/law breaker and the indigenous/native/national. It is worth noting that both of these are complexly and contingently related to "migration", 
and the migrant-citizen nexus could be a useful analytical lens to help tease out potential connections between these foundational categorisations.

Making up people "changes the space for possibilities of personhood" (Hacking $1986,165)$, and for "migrants" these changes are generally negative. While it is possible to imagine a world where incomers are feted and given privileges, in the world as it is, the "migrant" is a subordinated subject, and the possibilities of personhood for many migrants is severely constrained. This is, I suspect, why methodological nationalism, which is a problem pervasive to the social sciences, is particularly troubling for migration scholars. It exposes how our expert knowledge is implicated in nation state building processes that directly produce subordinated subjects.

\section{New Approaches to Researching "Migration" and Mobilities}

Key to Dahinden and my responses to the issues raised above is to challenge the uncritical importing of the category "migrant" into social scientific research. Dahinden distinguishes between the "common-sense categories" of politics and "analytical categories" of research: "Conflating them, and in particular using the common-sense categories in social scientific research is a central way in which researchers reproduce normalized migration and ethnic difference and the logic of the migration apparatus" (Dahinden 2016, 2213). My interest in the state-making nature of immigration controls means that I am particularly interested in the power and role of the law as a category producing mechanism, and the ways it blurs the distinction between categories of analysis and categories of practice. The law is explicitly constructive: It creates "migrants", or at least, creates first the foundational distinction of citizen/ non-citizen and then the multiple categorisations of non-citizen. The law also gives these differences significance: The law does not only describe who is allowed over a border, but also their conditions of life post-entry, how long they can stay, where they can work, their social and political rights and so on. Discrimination between citizens and certain groups of migrants is not only legal, but often legally required.

Laws must be respected and enforced, but assessing a person's legal status is extremely complicated. The general population is increasingly drawn into immigration enforcement, and poorly trained and anxious to err on the side of the law deputized actors often "directly reinforce symbolic and moral distinctions of otherness and illegality" (Walsh 2014, 247). In many states those charged with imposing immigration checks typically rely on race and/or ethnicity as a marker of national difference. In the UK this is precisely what happened in the Windrush scandal: The fact that people were Black was read as meaning they were migrants and potentially "illegal", and therefore their status was subject to heightened scrutiny. They were illegally evicted, sacked and in some cases even deported as a consequence. There is a developing area of scholarly work that seeks to explicate the relation between 
migration and "race" (Lentin 2008; Bhattacharya 2018; Yuval Davis et al. 2019; El-Enany 2020; Sharma 2020) but so far little attention has so far been paid to the role of "nationality". Nationality can be read as both a legal status, consonant with citizenship, AND as signifying belonging to the nation of the nation state. National membership in both senses is traced through ancestry and nationality is sutured to race. "A blurring of the vocabularies of nationality and race is a founding strategy of the modern nation-state that makes it impossible to inquire into the modern state without attending to its creation in a global context of colonialism and racism" (Mongia 2018, 113). It is not simply that migration is imagined as disturbing a previous national homogeneity, but that migration precipitated the emergence of nationality as a territorial attachment. Thus, not only is migration central to state development and rule rather than, as is often imagined, a challenge to it, but racism also is not an unfortunate characteristic of immigration enforcement, but is absolutely baked into immigration controls and enforcement (Goldberg 2002; Mongia 2018; El-Enany 2020).

One way of challenging the stigmatised status of "migrant" is to foreground the technicalities of legal status. While ethnic minorities may be more likely to have their papers checked, it is not only the negatively racialised and the poor who are deportable and subject to immigration controls. In the past decade, migration research has become far more attentive to the movement of the (relatively) privileged with a growing number of studies on expats, lifestyle migration and youth mobility schemes for example. The mobilities' paradigm has helped make connections between different kinds of human movements, between the mobilities of tourists and the movement of hospitality workers for example. Mobilities encourages us to think relationally and also to connect the mobilities of different kinds of things, the movement of goods with the movement of people for instance. Too often scholars are like the blind person feeling the elephant, missing the overall, and not connecting the migration trunk to a body which is trade, finance, history and infrastructure. In this way we risk replicating public understandings of migration which treats the movement of people as unattached to other economic, social and political processes. Thus, for example, in the UK the migration of significant numbers of people from the Caribbean to help build the National Health Service is much celebrated as a success of a tolerant and multicultural society - it was the centrepiece of the opening ceremony of the 2012 London Olympic Games in 2012. What is not visible is its relation to trade and profit: "When in about 1950 British democracy created a welfare state at home, it too depended on invisible donations from tea-pickers in Ceylon, rubber-tappers in Malaya, goldminers in South Africa, copper-miners in Rhodesia, the oil of Iraq and especially Iran" (Drayton 2012, 162). 


\section{Beyond Binaries: Migrant-Citizen Nexus}

Dahinden proposes the introduction of "the 'migrant-citizen nexus' concept - according to which not only citizens are migrantised, but migrants are also 'citizenised' - thereby revealing interconnections that otherwise remain invisible. This would indeed be a valuable tool to destabilise the binary thinking of migrant and citizen and the naturalisation of the "migrant". Some of those working on the undocumented/ illegalised categories of "migrant" emphasise the importance of not regarding "illegality" as an end state, recognising that immigration status as a process and that a person can move in and out of many different types of status. Similarly, the nexus proposal enables us to view citizenisation/migrantisation as processual rather than end states. This is important, as citizenship is too easily depicted as the "gold standard", the answer to the problem of the migrant as subordinated subject, when citizenship theorists have long challenged the assumption that citizenship is a status of equal membership in terms of diversity of race, gender, sexuality or disability. As Cohen puts it: "In the final analysis citizenship does not make a citizenry equal. In fact, it appears to institutionalize both difference and inequalities, albeit in sometimes unexpected ways" (Cohen 2009, 12).

To undertake such a project, we will need to integrate migration not only into social theory as Dahinden suggests, but also into political theory. The importance of nation state formation for the emergence of "the migrant" means that the migrant is an inescapably political figure which is of relevance to theories of state and people, nationalism, and democracy. This has been particularly developed in theories of citizenship where in the past twenty years migration has significantly reshaped contemporary theorisations.

Dahinden's "de-migranticization" and my "migrantizing the citizen" are complementary facets of the same project. We have a shared interest in not assuming a difference between migrants and non-migrants (whoever these may be). I suspect that our different emphasises are shaped by the fact that while we are both interested in "post migration studies" - I really like that description! - we are attached to the field for different reasons. Dahinden's primary interest is in knowing when being a migrant matters. Only once we have de-migrantized we can see the significance of migration both for the people themselves and for others. My primary interest is using "migration" as means to understand the conditions of marginalised populations more generally. The two are, in the final analysis, not possible to separate, and in fact we need both if we are to build on the insights of migration studies and move beyond them. 


\title{
The Migrant-Citizen Nexus in View of the Coronavirus Pandemic: Can We De-Migranticise Responses?
}

\author{
Janine Dahinden
}

Between the first and second rounds of this debate between Bridget Anderson and me, the context has changed dramatically, since the world was confronted with the coronavirus pandemic. Strikingly, European countries (and others, but I focus here on EU and Schengen member states) have fallen back on national(ist) answers. We are witnessing a closure along national lines, moving at a pace that was unimaginable a few weeks ago. Many European countries have closed their borders, some have implemented travel restrictions, others have imposed border controls, and on March 17, 2020 the European Council agreed to introduce a pan-European travel ban for the Schengen Area. ${ }^{2}$ European countries have retreated into national fortresses which, however, remain highly unequal within. Governments have presented these measures as inevitable, and as intending to prioritise their own citizens' needs over those of foreigners. In other words, the debate Bridget and I started a few weeks ago has acquired a new twist and meaning in view of this nationalist, culturalised and racialised response to the current pandemic.

In her seminal article, Bridget challenges the simplistic opposition between "migrant" and "citizen". She adopts the lens of "migrantising the citizen" to explore the many connections between the formal exclusion of non-citizenship and the multiple exclusions within citizenship. Building on her insights, I proposed the lens of the "migrant-citizen nexus" as a way to scrutinise citizenisation/migrantisation as an entangled processes. Analogously to Bridget's argument that citizenship does not make a citizenry equal, I argued that migrancy is also not equal and can be more or less citizenised. How can the migrant-citizen nexus help us make sense of Europe's nationalist reaction to COVID-19 and its consequences? What is currently happening to processes of citizenisation/migrantisation in Europe? I offer a tentative reading - of course highly selective and far from complete, rather $\grave{a}$ chaud, as we say in French - of some of these recent developments in terms of this migrancy/ citizenship debate. ${ }^{3}$

$2 \quad$ For an overview of the border closures, travel restrictions and border controls, see https:// www.lemonde.fr/planete/article/2020/04/12/coronavirus-dans-l-union-europeenne-ce-querevele-la-cartographie_6036364_3244.html?_ga $=2.229022748 .1490414115 .1586762015$ 160644985.1586762015 (19.6.2020), as well as data from nccr - on the move: https://public.tableau. com/views/Covid-19outbreak_15843550159920/Lists?:display_count=y\&publish=yes\&:origin=viz share_link\&:showVizHome=no (19.6.2020).

3 Please hold in mind, that this chapter was written during the peak of the "first wave" of the pandemic in early Summer 2020. 
In her seminal article, Bridget refers to the ways in which migration/integration scholars can implicitly or explicitly be involved in nation-state-making processes, a risk she calls "intellectual 'co-optation" - a term I like for its accuracy. She correctly argues that this concern is not specific to migration studies, but that migration studies have the particularity of dealing with a (legal and symbolic) category of people migrants/non-citizens - which emerged from nation-state-building processes and which has directly produced subordinated subjects. Yet, in view of the spread of the coronavirus, it is striking how swift migration scholars have been in offering important insights and voicing critical views - often in the form of blog entries, ${ }^{4}$ but also open calls ${ }^{5}$ - while showing a high degree of reflexivity with regard to the risk of intellectual co-optation. In other words, many migration and mobility scholars have applied already-existing critical knowledge to this new reality: They discussed the problematic aspects of travel restrictions, border controls and border closures in terms of their consequences for citizenship and unequal human im/mobility. They addressed the social inequalities that are inscribed in the capitalist system and migration regimes based on racialised, classed and gendered logics - for instance, when it comes to whether individuals have the privilege of being able to work from home, or even have access to sanitation infrastructure. Many have also reflected on the impact of these measures on asylum seekers and the human rights violations they result in. I interpret these voices as demonstrating that, as I argued in my first commentary, critical approaches that attempting to avoid intellectual co-optation not only have a long history within migration studies, but also have a great deal in common with a growing list of scholars outside mainstream migration studies who are also promoting similar reflexive knowledge.

But why does it remain so difficult to make these voices heard beyond academia? So far, politics and policies remain mostly untouched by this knowledge. In what follows, I reflect on what "de-migranticised" and "citizenised" - or, to use Bridget's term, "de-nationalised" - pandemic measures to protect vulnerable people could look like. Concretely, I use the migrant-citizen nexus to present some alternatives to the nationalism-based policies and measures that have been adopted in reaction to the coronavirus pandemic, and I focus on the Swiss case as a specific example of a more general pattern in Europe as a whole (and beyond).

$4 \quad$ Examples include COMPAS's Coronavirus and Mobility Forum at Oxford University: https:// www.compas.ox.ac.uk/project/the-coronavirus-and-mobility-forum/ (19.6.2020), and the nccron the move blog series, https://nccr-onthemove.ch/news-covid-19-and-mobility/ (19.6.2020),

5 An example is the open call by ERC-funded migration scholars for the EU to respect human rights. evacuate detained asylum seekers, halt deportations and radically revise EU migration policy: https://www.ethnos.gr/sites/default/files/images/2020/03/a_call_by_eu-funded_researchers.pdf (19.6.2020). 
Processes of Citizenisation and Migrantisation in View of the Pandemic

On March 13, 2020, the Swiss Federal Council announced border controls and closures during a news conference. The government argued that in order to ensure that the healthcare infrastructure in all the cantons could deal with the projected volume of COVID-19 cases, entry into Switzerland along its border with Italy would be restricted. In the words of the Federal Councillor in charge of the Federal Department of Justice and Police,

These measures are intended to protect the population of our country, namely the functioning of the healthcare system so that we have the capacity to treat our patients. We need to prevent people from Italy from coming here to be treated in our hospitals, especially in the border cantons of Ticino, Valais and Grisons. ${ }^{6}$

The Federal Council emphasised that these restrictions also applied to asylum seekers coming from Italy. "There's no need for asylum seekers to enter Switzerland because there's no immediate danger in Italy (which at this point was most heavily touched by the pandemic). Asylum seekers can ask for asylum in Italy and do not need to cross the border into Switzerland". The Federal Council emphasised that the border closure would be in accordance with both the Schengen Agreement on free movement and the Dublin Convention (see Daniel Thym's blog ${ }^{7}$ for the legal problems with these measures).

A few days later, the Federal Council imposed restrictions on entry by land and air to Italy, France, Germany, Austria, Spain and all non-Schengen states. On March $25^{\text {th }}$, it extended these restrictions to all remaining Schengen states with the exception of the Principality of Liechtenstein. Exempted from these restrictions are citizen of Switzerland and Liechtenstein, persons with a Swiss residence permit and persons who have to travel to Switzerland for work-related reasons or because of an emergency. ${ }^{8}$

A Foreign Virus and the Nationalist Lockdown: "De-Nationalising" the Pandemic by Framing it as a Global Crisis Requiring Non-National Solidarity

By framing the virus as foreign from the very beginning, European governments have culturalised and racialised it. Their policy responses have been consistent with this "Othering" of the virus - border controls and closures for people from foreign "risk areas", with exceptions for countries' own citizens (for whom costly efforts have

6 My translation. The press conference (in German and French) can be watched here: https:// www.youtube.com/watch?v=LFI7vQU-YnY\&list=PLEnHzNShzOwbxmvpk7ajVhE3m $1 \mathrm{mO6}$ h6p9\&index $=12 \& \mathrm{t}=0 \mathrm{~s}(19.6 .2020)$.

7 https://verfassungsblog.de/travel-bans-in-europe-a-legal-appraisal/ (19.6.2020.

$8 \mathrm{https} / /$ www.admin.ch/gov/en/start/documentation/media-releases.msg-id-78563.html (19.6.2020),. For an overview of all other measures (as of April 14), see https://www.swissinfo. ch/eng/covid-19_coronavirus--the-situation-in-switzerland/45592192 (19.6.2020). 
been made to repatriate them ${ }^{9}$ ). From the onset of the crisis, another framing was possible: It quickly became clear that, as with climate change we are faced with a global problem that requires both local and global action. Citizenising the pandemic would have entailed going beyond nationalist closures by highlighting solidarity and adopting non-national - local and international - measures.

\section{The Frame of the Universal Human Right to Health}

Is the strategy to protect "our" citizens and close borders to people coming from "risk areas" and "foreign countries" the most effective way to deal with this pandemic? Or, as Speranta Dimitru appropriately put it, "le nationalisme est-il bon pour la santé »? ${ }^{10}$ There are other possible strategies for dealing with the virus and protecting the most vulnerable - strategies that do not rely on nationality and race that would make it possible to citizenise the crisis in terms of universal human rights. The Universal Declaration of Human Rights (UDHR) guarantees a universal right to health, as a result of which access to healthcare can be reframed, from the protection of "our citizens" to the protection of all who need it. In other words, border controls - instead of outright border closures - might be useful, but they should be implemented independently of the nationality of the border crossers (for a more detailed argument, see Constantin Hruschka's b $\log ^{11}$ ). The screening of all arriving and departing persons, distribution of information material in multiple languages, isolation of persons suspected of being infected and transfer of the sick to healthcare facilities would be an alternative, and very effective, strategy (and one that Singapore has adopted). Or, as Hruschka put it, "Border controls should $[\ldots]$ rather be conducted for the purpose of health, i.e. the controls should aim to check whether or not a person is potentially carrying the virus. This would mean no passport or residence permit checks but temperature and corona tests". Such an approach could circumvent the migrantising effects of travel restrictions that have been highlighted by many scholars (see, for instance, Lorenzo Piccoli ${ }^{12}$ ): Border closures jeopardise the lives of the most vulnerable, like migrants who find themselves unable to return to the countries where they are supposed to study, work or care for their families. Instead of migrantising people, such an approach would citizenise them. Very exceptionally, there have been some efforts that hint at a universalising citizenship regime: Switzerland and Germany, among others, have taken a small number of patients from France and Italy. ${ }^{13}$ Additionally, such an outlook would have

9 For Switzerland, see for instance https://www.admin.ch/gov/en/start/documentation/media-releases. msg-id-78550.html (19.6.2020).

10 https://theconversation.com/le-nationalisme-est-il-bon-pour-la-sante-135709 (19.6.2020).

11 http://eumigrationlawblog.eu/the-pandemic-kills-also-the-european-solidarity/ (19.6.2020).

12 https://www.washingtonpost.com/politics/2020/04/05/coronavirus-restrictions-movement-mayjeopardize-lives-most-vulnerable/ (19.6.2020).

13 For the numbers, see https://www.lemonde.fr/planete/article/2020/04/12/coronavirus-dansl-union-europeenne-ce-que-revele-la-cartographie_6036364_3244.html?_ga=2.229022748. $1490414115.1586762015-160644985.1586762015$ (19.6.2020). 
meant that, instead of introducing measures to prevent Italians (living near the Swiss border) from being treated in Swiss hospitals, Switzerland could have facilitated the exchange of patients between hospitals from different cantons: In late March 2020, healthcare infrastructure in Ticino, the first canton affected by the coronavirus, was under heavy strain, in contrast to German-speaking cantons, where, because the virus arrived later and safety measures were introduced early enough, healthcare infrastructure was never strained beyond its limits in 2020 .

\section{Filtering the Borders for Nationalist Purposes: Reinforcing Inequalities}

Ironically, the Swiss healthcare system functions partly thanks to the very high number of Italian healthcare workers in Ticino, as well as German and French healthcare workers in Switzerland's other linguistic regions. These individuals have become "system relevant" workers (or who in English are referred to as "key workers"). Such workers are often women and migrants, and they are mostly poorly paid. In this particular situation, they have been citizenised in the sense that they are still permitted to cross the border. Simultaneously, and cynically, their families and friends cannot receive treatment in Swiss hospitals. As Van Houtum $(2005,673)$ has argued, bordering processes are always entangled with ordering and othering, and border regimes always filter individuals according to particular criteria, but this has become almost absurdly obvious during the pandemic: We let others enter as long as it is for our benefit. We are witnessing this attitude throughout Europe, mainly in regard to agricultural and hospital workers. The vivid debate about whether to "import" Romanians and Bulgarians to Germany via special (expensive) flights to harvest asparagus for low wages reveals some of these inequalities and filtering mechanisms within Europe. At the same time, jobs which are typically performed by migrant workers are also being citizenised: Again in Germany, for example, massive efforts have been made to recruit German replacements for foreign harvest workers. These replacements could come from "the unemployed", but also from among those who are temporarily unemployed because of the lockdown.

\section{Racialisation and Culturalisation: Überfremdung Reloaded}

In Switzerland, the virus has been culturalised and racialised in a particular way, but similar mechanisms are observable elsewhere (see Bridget's postscript). A prominent Swiss geographer has explained the high number of COVID-19 fatalities in Italy, Spain and France, as well as the higher fatality rates in Switzerland's Italianand French-speaking regions relative to its German-speaking regions, as resulting from differences in "culture". ${ }^{14} \mathrm{He}$ has claimed that the virus spreads faster in the

14 https://twitter.com/mhermann_/status/1241626700070486017 (19.6.2020), Leaving everything else aside, the data he presents is highly questionable. To calculate fatalities per million inhabitants without taking into account case incidences or the time when the virus arrived and social-distancing measures were introduced, for example, is clearly unsound. 
"Latin-speaking area" than in the German-speaking area because social distancing is a culturally determined phenomenon, and that German-speaking Switzerland therefore needs to be cautious about adopting "Latin measures". These arguments were picked up by a populist journalist who has argued that the different rates of infection in French- and German-speaking regions can be explained by their different, historically grounded "mentalities", especially their attitudes regarding state benefits and economic responsibility. ${ }^{15}$ This type of culturalisation and othering, which comes at the cost of ignoring systems of dominance and power, is common in Switzerland. It echoes concerns about Überfremdung ("over-foreignisation"), a Swiss term with origins in the late nineteenth century which was re-appropriated by various populist parties in the twentieth and twenty-first centuries in order to argue against immigration. At the core of Überfremdung is the fear that too much or certain forms of immigration will compromise Switzerland's cultural identity and integrity as a nation, and that migrants should therefore not be allowed to enter because they are culturally too different (Kury 2003; Fischer and Dahinden 2017). What is surprising, however, is that this culturalising and exclusionary discourse stopped being targeted at European "migrants" years ago and has instead come to focus mainly on Muslims and migrants from non-European countries. The coronavirus seems to have enabled a reloading of culturalising and racialising ideas from the past by once again targeting them at groups that had come to be seen as belonging to Europe and hence "like us". The virus has also been used to revitalise imagined insurmountable differences between German and French speakers, thus culturalising majority-minority power relations. These forms of culturalising are not only essentialist and reifying, but historically have also always been mobilised in order to secure socio-economic and structural privileges among the Swiss or the Swiss-German majority - a function that culturalisation and racialisation have fulfilled in most European countries (Hall 1997; Phillips 2010).

\section{Migratisation of European citizenship}

The Swiss example points to a transformation of European citizenship towards a migrantisation of EU citizens living in other member states. European citizenship, with its freedom of movement for nationals within the EU, was one of the most developed forms of "post-national membership" in the world (Soysal 1994). Through a case study of the United Kingdom and Germany, Barbulescu and Favell (2020) have shown that the principle of free movement in the EU had been transformed into a specific form of "immigration" and a way of limiting access to welfare to EU citizens even before the coronavirus pandemic. The freedom of movement of persons has increasingly been seen as problematic and framed as welfare tourism and poverty migration, including in Switzerland. But governments' reaction to

15 https://www.thurgaukultur.ch/magazin/weshalb-das-virus-den-thurgau-am-wenigsten-trifft-4375 (19.6.2020). 
the crisis has increased this migrantisation of EU citizens to an extent that would have been unimaginable before this crisis. This is especially remarkable, because the severe restrictions of cross-border movements in Europe were mostly not been accompanied by restrictions on domestic mobility. While Switzerland has closed its borders and imposed travel restrictions in 2020, the public transportation system continues to work (albeit at reduced volume) and people are in principle permitted to travel throughout Switzerland - even though the government urges the population to stay home (some countries, including Spain and Italy, have restricted internal mobility). Is travelling between Geneva and St. Gallen less dangerous than travelling between Geneva and Hamburg? If so, it would probably make sense to treat this crisis regionally, perhaps by limiting mobility in the most heavily affected regions.

\section{Asylum Seekers: From (Partial) Human Rights Protection to Migrantisation}

We can observe a clear de-citizenisation and a reinforced migrantisation in the context of asylum. Human rights regimes offer a road towards citizenisation. Some of the rights afforded to asylum seekers by the UDHR and the refugee system based on it are currently under attack. Border closures affect people seeking protection - as the Swiss Federal Council's news conference I discussed above demonstrates - since these people are also foreigners who should be prevented from entering the country. According to Hruschka, denying entry to persons seeking protection is a violation of international law. ${ }^{16}$ Additionally, asylum seekers are the ignored vulnerable during this crisis. The situation in refugee camps in Greece and elsewhere, where Europe is failing to showing any solidarity, is catastrophic, and social distancing is mostly impossible in Switzerland's asylum centres, as grassroots organisations have been arguing since the pandemic reached the country. ${ }^{17}$

\section{A Plea for Citizenising Measures in the Face of the Pandemic}

Examining the current situation through the migrant-citizen nexus reveals a tendency within Europe to simultaneously migrantise some people, mainly the most vulnerable, and citizenise others, mainly the most privileged, reinforcing established gendered, racialised and classed inequalities. The arguments I raise here are partly well-established ones that date to pre-pandemic times and circumstances, but which may now have a chance to break out of the "echo chamber". I have attempted to outline some avenues by which we could move towards a citizenised response to the coronavirus pandemic, which could contribute to outcomes that are less nationalistic and unequal. I would like to reiterate an argument I made in my original commentary, but which has become much more urgent: Migration scholars need to step outside of academia and reach out to policymakers and wider audiences. Together with the

16 http://eumigrationlawblog.eu/the-pandemic-kills-also-the-european-solidarity/ (19.6.2020).

17 See also https://www.woz.ch/2015/asylpolitik/ausgeliefert-im-bunker (19.6.2020). 
many grassroots solidarity networks, we must do everything possible to contribute to the creation of a world of citizenship rights, which are not restricted by nationality.

\section{COVID Postscript}

\section{Bridget Anderson}

Re-reading our work from only a few weeks' ago is surreal. It seems like a message from an old world and, to paraphrase Gramsci, as the new one struggles to be born, who knows what monsters will emerge. As I write, citizens of wealthy democracies are confined in ways that would have been unimaginable even one month ago. In England no person may leave the place where they live "without a reasonable excuse". Leaving home for the purposes of "buying paint and brushes simply to redecorate a kitchen", or "driving for prolonged period with only brief exercise" for example do not constitute acceptable reasons (College of Policing 2020). In the US several states have introduced border checkpoints and are targeting motorists with out of state licence plates. In Spain the Guardia Civil have been given the power to check any documentation that can prove a person's reason for being outside, including shopping receipts. These are the kinds of measures with which non-citizens or citizens on probation may be familiar but are extraordinary for most. They are compounded by the experience of a kind of "asylum seeker time", an unrolling and flat present, a temporariness that extends until we-know-not-when, and over which people have limited control.

Public health is an instantiation of the "migrant/citizen nexus". It exposes our species being-in-common as the micro-biological does not recognise passports or bank balances. In that sense "we are in this together". Yet the analysis and responses to the pandemic are very much through a national lens. While the pandemic is global, the metaphors of being "at war", fighting and enlisting are promoted as if other humans were the enemies. In the UK we watch the daily press briefings flanked by Union Jacks and Georgian panelling and listen to comparisons with other states while the government seeks to explain the relative steepness of our "curve". In the early days countries would refer smugly to their national cultures: "Italians' demonstrative nature could be contributing to the spread of coronavirus", "The lifestyle and diet of Myanmar citizens are beneficial against the coronavirus". However, national thinking can be misleading and methodological denationalism has the potential to help us identify key issues that overly focussing on this scale obscures.

Firstly, thinking nationally suggests that those residing on the same territory are "in it together". Now of course it is undeniable that the state where people were present at the time of the virus has direct consequences for their health. Na- 
tional governments are responding quite differently to the public health crisis, and their responses affect rates of sickness and death. However, the virus also exposes the mechanisms that promote and maintain inequality within as well as between states. For example, in UK, Sweden and the USA, among other countries, evidence is emerging that Black and Minority Ethnic people are disproportionately likely to catch and die from coronavirus. Increased susceptibility is in part because of poorer living conditions and long-term health inequalities, but also the likelihood of working in "forward facing" and essential jobs - in the UK the first ten named doctors to die from COVID-19 were all from minority ethnic backgrounds. The virus infected regardless of race, class and passport, and this is precisely what exposes race, class and passports as the inequality producing mechanisms that they are, as certain populations are far more likely to sicken and die.

These discrepant vulnerabilities and their association with race and class divisions are acknowledged, but citizenship status has so far been overlooked in reports and data on those who have caught and died from the virus. Non-citizens account for a substantial share of employment in many sectors that are now defined as essential. This includes health professionals: In Switzerland 34\% of doctors are non-citizens, in the UK it is $28 \%$ (Baker 2019) and a report by the Migration Advisory Committee found that migrant nurses are paid significantly less than their UK national colleagues (Migration Advisory Committee 2016, Annex B).

The legal restrictions that are part of "making up migrants" are a key element in the interaction between the socio-economic and the biological that has consequences for everyone's public health. This interaction is key to the origin and spread of the virus, and again nationalist assumptions mean we miss how the multiple intersections of (im)mobilities of capital, of food, of humans, of animals, of the microbiological, have produced the contemporary situation. The COVID virus is a human infection of animal origin, and the outbreak is likely to have originated in a market selling dead and live wild animals as food. However, to see the virus as originating in China is to miss the powerful transnational forces at play because of a distraction with the scale of the national. Across the world, big business has undermined local food security, pushing smallholders off their land and fisherfolk from their fishing grounds, increasing the cost of food and making subsistence more difficult. As price of protein has risen, the urban poor have turned to wild game, and rural people have moved to land that is more difficult to cultivate, sometimes encroaching on areas previously uninhabited by human populations, exposing them to new animal harms. Factory farming too has driven the emergence of new diseases. The mass "production" of livestock crowds together millions of farmed animals in breeding grounds for disease and species jumping (Wallace et al. 2020). Livestock production and multinational agribusinesses are owned and controlled by a handful of multinational corporations - JBS, Tyson Foods, Cargill and Smithfields (the last owned by the Chinese WH Group). Powerful transnational financial interests are 
also invested in them: For example, after the 2008 financial crisis Goldman Sachs bought into Chinese poultry farms - reservoirs of avian $\mathrm{flu}^{18}$. Methodological denationalism can help develop the kind of relational thinking that locates the origins of the crisis - and therefore its long term solutions - not in a single animal in a wet market in Wuhan, but in entanglements whose "knots" are not only in Beijing and Hong Kong but also in New York, London and Paris.

This is particularly important in a situation where the virus is already being used as an excuse for brutal crackdowns. Border closures have been used to limit spread for centuries - the word "quarantine" comes from the $14^{\text {th }}$ century Venetian practice of requiring ships from infected ports to sit at anchor for 40 days, quaranta giorni, before landing. In the contemporary world it is a measure associated with strong government, with taking action to protect the nation. "This is why we need borders" tweeted President Trump, directing attention to the borders and away from the internal community spread and chronic failures that facilitated it. Hungarian President Viktor Orban not only closed Hungary's borders but also its universities on the grounds that "we cannot separate the tens of thousands of foreign students from the Hungarian students", inadvertently demonstrating a key slippage that nationalism facilitates: Associating spread not with movement but with foreignness and ethnicity. The fact is that, in a globally integrated economy, international movement cannot be simply halted. This is illustrated by the continuing demand for temporary migrants to harvest crops across Europe in the Spring and Summer of 2020. The European Commission advised that agricultural workers be permitted to cross European borders while Germany, the UK, Italy and Spain desperately sought to recruit seasonal pickers. Movement, it seems, is necessary to "keep us safe, healthy and with food on the table"19.

Milton Friedman wrote: "Only a crisis - actual or perceived - produces real change. When that crisis occurs the actions that are taken depend on the ideas that are lying around" (Friedman1982, xiv). Times like this expose how politicised judgements of reasonableness and realism are. A national lens normalises strict mobility controls, hyper surveillance and the ready association of race and disease, it distracts from the powerful financial and industrial interests that today shape the interface between the socio-economic and the biological today. Bizarrely, it makes preventing human movement more imaginable than planetary public health at a time when our energies should be devoted to the latter.

18 https://thepoultrysite.com/news/2008/08/goldman-sachs-buys-chinese-poultry-farms.

19 (https://www.euractiv.com/section/agriculture-food/news/eu-recommends-keeping-borders-openas-agri-labour-conundrum-looms-large/. 


\section{References}

Amelina, Anna, and Thomas Faist. 2012. De-Naturalizing the National in Research Methodologies: Key Concepts of Transnational Studies in Migration. Ethnic and Racial Studies 35(10): 1707-1724. Doi: 10.1080/01419870.2012.659273.

Anderson, Bridget. 2019. New Directions in Migration Studies: Towards Methodological Denationalism. Comparative Migration Studies 7(1):1-36. Doi: 10.1186/s40878-019-0140-8.

Baker, Carl. 2019. NHS Staff from Overseas: Sstatistics. House of Commons Library Briefing Paper no. $77838^{\text {th }}$ July, https://researchbriefings.files.parliament.uk/documents/CBP-7783/CBP-7783. pdf (20.06.2020).

Barbulescu, Roxana, and Adrian Favell. 2020. Commentary: A Citizenship without Social Rights? EU Freedom of Movement and Changing Access to Welfare Rights. International Migration 58(1): 151-165. Doi: 10.1111/imig.12607.

Bhattacharya, Gargi. 2018. Rethinking Racial Capitalism: Questions of Reproduction and Survival. Maryland: Rowman \& Littlefield.

Bonjour, Saskia, and Laura Block. 2016. Ethnicizing Citizenship, Questioning Membership. Explaining the Decreasing Family Migration Rights of Citizens in Europe. Citizenship Studies 20(6-7): 779-794. doi: 10.1080/13621025.2016.1191429.

Carling, Jorgen. 03.07.2017. Thirty-Six Migration Nexuses, and Counting, in Jørgen Carling, https:// jorgencarling.org/2017/07/31/thirty-six-migration-nexuses-and-counting/ (20.06.2020).

Cohen, Elizabeth. 2009. Semi-Citizenship in Democratic Politics. Cambridge: Cambridge University Press.

College of Policing. 2020. What Constitutes a Reasonable Excuse to Leave the Place Where You Live. Coventry: Collegeof Policing, https:/www.college.police.uk/What-we-do/COVID-19/Pages/ Understanding-the-Law.aspx (20.06.2020).

Crawley, Heaven, and Dimitris Skleparis. 2017. Refugees, Migrants, Neither, Both: Categorical Fetishism And the Politics of Bounding in Europe's "Migration crisis". Journal of Ethnic and Migration Studies, 44(1): 48-64. Doi: 10.1080/1369183X.2017.1348224.

Dahinden, Janine. 2016a. A Plea for the 'De-Migranticization' of Research on Migration and Integration. Ethnic and Racial Studies 39(13): 2207-2225. Doi: 10.1080/01419870.2015.1124129.

Dahinden, Janine. 2016b. Switzerland. In The Wiley-Blackwell Encyclopedia of Race, Ethnicity and Nationalism, edited by John Stone, Dennis Rutledge, Polly Rizova and Anthony Smith. JohnWiley \& Sons. Retrieved from Wiley Online Library. Doi: 10.1002/9781118663202.

Dahinden, Janine, Carolin Fischer, Joanna Menet, and Anne Kristol. 06.09.2018. Gendernationalism As a new Expression of Political Nationalism, in GenderCampus, https://www.gendercampus. $\mathrm{ch} / \mathrm{en} / \mathrm{blog} /$ post/gendernationalism-as-a-new-expression-of-political-nationalism/ (20.06.2020).

Dahinden, Janine, Carolin Fischer, and Joanna Menet. 2020. Knowledge Production, Reflexivity, and the Use of Categories in Migration Studies: Tackling Challenges in the Field. Ethnic and Racial Studies: 1-20 (IFirst). Doi: 10.1080/01419870.2020.1752926.

De Genova, Nicholas. 2017. The "Migrant Crisis" as Racial Crisis: Do Black Lives Matter in Europe? Ethnic and Racial Studies 41(10): 1765-1782. Doi: 10.1080/01419870.2017.1361543.

Drayton, Richard. 2012. Imperial History and the Human Future. History Workshop Journal 74(1): 156-172. Doi: 10.1093/hwj/dbr074.

El-Enany, Nadine. 2020. (B)ordering Britain: Law, race and empire. Manchester: Manchester University Press.

Favell, Adrian. 2015. Integration Policy and Integration Research in Western Europe: A Review and Critique. Pp. 69-122 in Immigration, Integration and Mobility: New Agendas in Migration Studies 1998-2014, edited by Adrian Favell. Colchester: ECPR Press. 
Favell, Adrian. 2016. Just Like the USA? Critical Notes on Alba and Foner's Cross-Atlantic Research Agenda. Ethnic and Racial Studies 39(13):2352-2360. Doi: 10.1080/01419870.2016.1203447.

Swiss Federal Office for Public Health, Internationnal Center for Migration Policy Development and Swiss Forum for Migration, and Population. 2011. Access to Healthcare for Undocumented Migrants in Switzerland. Policies-People-Practices. Vienna: Communication Network.

Fischer, Carolin, and Janine Dahinden. 2017. Gender Representations in Politics of Belonging: An Analysis of Swiss Immigration Regulation From the $19^{\text {th }}$ Century Until Today. Ethnicities 17(4): 445-468. Doi: 10.1177/1468796816676844.

Friedman, Milton. 1982. Capitalism and Freedom, Chicago: University of Chicago Press.

Goldberg, David Theo. 2002. The Racial State. Oxford: Blackwell Publishing.

Hacking, Ian. 1986. Making Up People. Pp. 161-171 in The Science Studies Reader, edited by Mario Baigioli. New York, NY: Routledge.

Isin Engin and Nielson, Brett (eds). 2008. Acts of Citizenship. New York: Palgrave Macmillan.

Khazai, Faten. 2019. Manufacturing Difference. Double Standard in Swiss Institutional Responses to Intimate Partner Violence. PhD-thesis, University of Neuchâtel, Switzerland.

Korteweg, Anna C. 2017. The Failures of 'Immigrant Integration': The Gendered Racialized Production of Non-Belonging. Migration Studies 5(3): 428-444. Doi: 10.1093/migration/mnx025.

Kristol, Anne, and Janine Dahinden. 2019. Becoming a Citizen Through Marriage: How Gender, Ethnicity and Class Shape the Nation. Citizenship Studies 24(1): 40-56. Doi: $10.1080 / 13621025.2019 .1691152$.

Kury, Patrick. 2003. Über Fremde reden. Überfremdungsdiskurs und Ausgrenzung in der Schweiz 1900-1945. Zürich: Chronos.

Lentin, Alana 2008, Europe and the Silence About Race. European Journal of Social Theory 11(4): 487-503. Doi: 0.1177/1368431008097008.

Malkki, Liisa. 1992. National Geographic: The Rooting of Peoples and the Territorialization of National Identity Among Scholars and Refugees. Cultural Anthropology 7(1):24-44.

Michel, Noémi. 2015. Sheepology: The Postcolonial Politics of Raceless Racism in Switzerland. Postcolonial Studies 18(4): 410-426.

Migration Advisory Committee (MAC). 2016. Partial Review of the Shortage Occupation List: Review of Nursing. London: Crown copyright. https://assets.publishing.service.gov.uk/government/ uploads/system/uploads/attachment_data/file/510630/Partial_review_of_the_shortage_occupation_list_-_review_of_nursing.pdf (20.06.2020).

Mongia, Radhika. 2018. Indian Migration and Mpire: A Colonial Genealogy of the Modern State. Durham: Duke University Press.

Ossipow, Laurence, Anne-Laure Counilh, and Milena Chimienti. 2019. Racialization in Switzerland: Experiences of Children of Refugees From Kurdish, Tamil and Vietnamese Backgrounds. Comparative Migration Studies 7(1): 1-7. Doi: 10.1186/s40878-019-0117-7.

Phillips, Anne. 2010. What's Srong With Essentialism? Scandinavian Journal of Social Theory 11(1): 47-60. Doi: 10.1080/1600910X.2010.9672755

Purtschert, Patricia, and Harald Fischer-Tiné. 2015. Introduction. The End of Innocence: Debating Colonialism in Switzerland. Pp. 1-23 in Rethinking Colonialism from the Margins, edited by Patricia Purtschert and Harald Fischer-Tiné. Basingstoke: Palgrave Mcmillan.

Scalettaris, Giulia. 2007. Refugee Studies and the International Refugee Regime: A Reflection on a Desirable Separation. Refugee Survey Quarterly 26(3): 36-50.

Schinkel, Willem. 2018. Against "Immigrant Integration": For an End to Neocolonial Knowledge Production. Comparative Migration Studies 6(31): 1-17. Doi: 10.1186/s40878-018-0095-1. 
Sharma, Nandita. 2020. Home Rule: National Sovereignty and the Separation of Natives and Migrants. Durham North Carolina: Duke University Press.

Soysal, Yasemin Nuhoglu. 1994. Limits of Citizenship: Migrants and Postnational Membership in Europe. Chicago: University of Chicago Press.

Studer, Brigitte. 2001. Citizenship as Contingent National Belonging: Married Women and Foreigners in Twentieth-Century Switzerland. Gender \& History 13(3): 622-654. Doi: 10.1111/14680424.00246 .

Torpey, John. 2000. The Invention of the Passport. Surveillance, Citizenship and the State. Cambridge, New York: Cambridge University Press.

Van Houtum, Henk. 2005. The Geopolitics of Borders and Boundaries. Geopolitics 10(4): 672-679. Doi: $10.1080 / 14650040500318522$.

Van Houtum, Henk, and Rodrigo Bueno Lacy. 2019. The Migration Map Trap. On the Invasion Arrows in the Cartography of Migration. Mobilities 15(2): 1-24. Doi: 10.1080/17450101.2019.1676031.

Wallace, Robert, Alex Liebman, Luis Chaves, and Rodrick Wallace. 2020. COVID-19 and Circuits of Capital. Monthly Review 72(1). https://monthlyreview.org/2020/05/01/covid-19-and-circuitsof-capital/ (20.06.2020).

Walsh, James. 2014. Watchful Citizens: Immigration Control, Surveillance and Societal Participation. Social and Legal Studies 23(2): 237-259. Doi: 10.1177/0964663913519286.

Wimmer, Andreas, and Nina Glick Schiller. 2002. Methodological Nationalism and Beyond: NationState Building, Migration and the Social Sciences. Global Networks 2(4): 301-334. Doi: 10.1111/1471-0374.00043.

Yuval-Davis, Nira, George Wemyss, and Kathryn Cassidy. 2019. Bordering. Cambridge: Polity Press.

Zetter, Roger. 1991. Labelling Refugees: Forming and Transforming a Bureaucratic Identity. Journal of Refugee Studies 4(1): 39-62. Doi: 10.1093/jrs/4.1.39. 